\title{
The Triumph of Pan: Hermaphroditism and Sexual Inversion in Victor Benjamin Neuburg's Poetry
}

\begin{abstract}
The Greco-Roman god Pan was particularly significant for late-nineteenth- and early-twentieth-century literature, especially that produced by the Decadent movement in England and abroad. This is not surprising, given the features that Pan shares with the Decadent movement, features that proved oppositional to the moral and social norms that developed during the Christian period. Pan also had special significance for the occult and homoerotic practices that dominated the relationship between the famous magician, occult writer, Decadent poet, and general contrarian Edward Aleister Crowley (1875-1947) and his apprentice in the art of sexual magic, Victor Benjamin Neuburg (1883-1940), who was himself a Decadent poet, one whose memorable collection of poems is entitled The Triumph of Pan (1910). The present paper focuses on the motifs of hermaphroditism and sexual inversion that dominate Neuburg's title-poem "The Triumph of Pan," motifs that appear in two important theories of the period that influenced Neuburg. The first is Crowley's prediction of the age that will overcome the Judeo-Christian period, an age represented by the androgynous Egyptian god Horus, and the second is the concept of the intermediate sex, denoting individuals who possessed both male and female characteristics, advanced by Edward Carpenter (1844-1929), a sex reformer and writer on homosexuality. In both Crowley's and Carpenter's writing reforming attitudes to sex is connected with opposition to organised religion, the Judeo-Christian in particular.
\end{abstract}

\section{Key words}

Victor Benjamin Neuburg; Aleister Crowley; Edward Carpenter; Pan; homoerotic; gender; sexuality

Victor Benjamin Neuburg (1883-1940) was born in a period which had been famously described by George Gissing as a period of "sexual anarchy" (Showalter 
1992: 3). With feminism, emerging in the shape of New Women, and a "burgeoning homosexual subculture," far from being suppressed by the Labouchere Amendment criminalising "all male homosexual acts" (14-15), the neatly defined Victorian categories concerning gender and sexuality began to crumble, giving rise to new concepts denoting people who did not fit, the in-betweens, as "Inverts, Hermaphrodites, Uranians, Urnings and Intersexes" (Kaye 2007: 62). Indeed, it was in this period that "the homosexual was 'invented' by medical sexology as a separate species from the heterosexual" (60). Showalter aptly described this period as not only "a battle between the sexes" (with men resenting women's struggle for emancipation), but also "within the sexes" (1992: 9, original emphasis), with people trying to grapple with changes in gender and sexual identities. The changes in thinking about gender and sexuality went hand in hand with a shift in religion. Many fin-de-siècle writers turned away from Christianity, embracing Eastern spirituality and/or New Paganism, which were, among other things, more sexually liberal. In 1910, when Neuburg's collection of poems The Triumph of Pan was published, the battle of the sexes was not over.

"The Triumph of Pan," the title poem of the collection and the focus of the present article in many way reflects the turbulent period of the turn-of-the-century, being notable for its concern with sexual and gender ambiguity, expressed through the themes of hermaphroditism and sexual inversion, and the relation of these themes to organised religion, Christianity in particular. The poem is informed by the theories of two major fin-de-siècle thinkers who greatly influenced Neuburg: Edward Carpenter (1844-1929), "a pioneer sex reformer who wrote on homosexuality, the emancipation of women and mutuality in loving" (Rowbotham 2009: 1), and Edward Aleister Crowley (1875-1947), the famous magician, occult writer, and Decadent poet. Specifically, Neuburg was interested in Carpenter's notion of "double nature," used to denote people who had both male and female attributes and who were attracted to both sexes (Carpenter 1912: 22). The notion was elaborated in Carpenter's book The Intermediate Sex (1908), a defence of homosexual love, and a book which strongly influenced Neuburg (Fuller 1990: 128). Crowley entertained a similar notion in The Book of the Law (1904), in which he theorised three aeons of mankind, the last of which - the Aeon of Horus - is characterised by a union of male and female attributes embodied in the androgynous figure of the Egyptian god Horus. Similarly, Carpenter saw "his intermediates as harbingers of the new age" (Rowbotham 2009: 283). Carpenter and Crowley also shared a critical view of what they saw as repressive attitude to sex and body in Christianity. Neuburg gives their theories lyrical expression in "The Triumph of Pan."

Neuburg is a rather obscure poet and not much has been written on his work. Undoubtedly, he has been overshadowed by his infamous master. Apart from his biography The Magical Dilemma of Victor Neuburg by Jean Overton Fuller and the short memoir Vickybird written by his son, he is mentioned in works concerning Crowley. From these, Alex Owen's article "The Sorcerer and His Apprentice," is especially pertinent to the present article, describing the magic ritu- 
als performed in the Algerian desert, which gave rise to Neuburg's poem "The Triumph of Pan", the title poem of the collection of the same name.

Exploring the world of Victor Benjamin Neuburg means entering the realm of magic - the world of fin-de-siècle magical orders, most famous of which was the Hermetic Order of the Golden Dawn. Neuburg was closely associated with Crowley, who had been a member of the Order of the Golden Dawn, but after conflicts with W. B. Yeats and the ensuing "power struggle" (Owen 1997: 103), he left it and later established his own magical order, the Order of the Silver Star. When Neuburg met Crowley, he "was already a published poet" (Owen 2004: 192). Crowley knew his work and sought him out because he "had been attracted by the mystical leanings in his work" (192). Neuburg became Crowley's a chela, "a novice initiate" of his magical order (1997: 99). As such, he "had taken a vow of obedience to Crowley as his Master," which basically meant that "Crowley's word was now law" (99). This fact alone indicates quite clearly just how important an influence Crowley was for Neuburg; he was in awe of Crowley, "whom he both loved and admired" (99). In 1909 the two men travelled to Algeria to perform magic rituals aimed at developing techniques of sex magic (100). This experience gave rise to Neuburg's poem "The Triumph of Pan".

Apart from an interest in mysticism, the two men also shared opposition to organised religion, both of them rejecting their religious background. Crowley felt a deep loathing for Christianity, brought about by the effect its practice had on his mother and his father, specifically the life-negating asceticism of his mother (Churton 2012: 6) and the death of his father, which might have been avoided if it had not been for the "misguided cancer treatment" recommended to him by the Plymouth Brethren Christian sect (5). Consequently, Crowley made it "his mission ... to 'make war on the saints' of meek, self-denying Christendom, and to bring in a religion for the strong" (Fuller 1990: 109). Similarly, Neuburg, held markedly different views on religion from those of his family, having "rejected conventional Judaism along with all organized religion" and "espous[ing] Freethought views and progressive values" (Owen 2004: 193). This is expressed in his poem "Vale Jehovah!":

What if to the Race I was born?

To me that's no reason why I

Should cling to a faith that I scorn,

When my birthright's the infinite sky!

Thy yoke I for ever throw over! (qtd. in Fuller 1990: 104, original ellipsis)

Both Neuburg and Crowley deeply despised the conformity and propriety typical of Victorian England. For Neuburg, this was embodied in his Aunt Hannah,

whom he called Frau B, until he shortened it to Fraub, which later became his generic name for any woman of the type of an overbearing Mrs Grundy. 
She always knew what was 'right' to do in any circumstances and she would say, 'in my opinion,' in a way that maddened Vicky, for everything pronounced following these words was held to be incontrovertible. She was a woman of invincible propriety. It would be impossible to overestimate her influence; his whole life was a rebellion against her. (Fuller 1990: 100)

Neuburg, as a freethinker, was in his views diametrically opposed to the conservatism of his family. Although his family were not unkind, he could not bear their "stuffiness" (101). Being naturally very contemplative and perceptive, childhood was a traumatic part of his life: "[I]n the stifling atmosphere in which he had been brought up anything which he did spontaneously or that was any fun was displeasing God. God was not merely the God of Vengeance; he was Fraub, arguseyed. The discovery that there existed people who did not believe in the existence of this ogre was electrifying and liberating" (103).

Neuburg was "dreamy and mystical by nature" (Owen 1997: 99). In fact, he "experienced mystical states in childhood" (2004: 193). He was described by his acquaintances as "elfin and "faunlike" in appearance (1997: 107), and by one of his friends as "awfully goat-like" (130). This must have made him particularly eligible for the rituals in the Algerian desert, in which he came to invoke and then embody the god Pan. The similarity between the apprentice and the god was further accentuated by Neuburg's hair: his "head was shaved, leaving only two tufts at the temples which were "twisted up into horns"' (104). The purpose of this was to make the locals think Neuburg was actually "a demon compelled by magick to serve Crowley" (Churton 2012: 163) and, in this way, to raise Crowley's esteem. During the Algerian rituals, Crowley was "sodomized by Neuburg in a homosexual rite offered to the god Pan" (Owen 1997: 101), whom he worshipped "as the diabolic god of lust and magic" (107).

Neuburg's poem "The Triumph of Pan" was undoubtedly inspired by the rituals performed in Algeria, in the northwest of Africa. The poem takes place "in the waiting west" (XVIII) and draws on the imagery of the desert:

The ways have parted, and the sun is glowing

Over the eternal sand,

And the endless road grows steeper; we are going

Into a nameless land. (XXI)

But the part that reveals the origin of the poem quite unambiguously is when the poet says: "And I am grown a god, a sinewy token / Of Pan's most ardent strife" (VI), which clearly describes Neuburg's invocation of the god Pan. Finally, the lines "O world of shadows, slowly disappearing / Under the Master's wand!" (XXXIII) contain a reference to Crowley, the person whose every command Neuburg, as his chela, obeyed, the wand being a symbol of Crowley's status as a magician.

The title of the poem, "The Triumph of Pan," reveals the main topic and the most important motif. The question remains what kind of a triumph it celebrates, 
or more specifically, over what or whom Pan triumphs. At the beginning, the poet encounters three gods: "The first a woman" who seduces the poet "with burning glances mingled / With longings soft and pure ... To ease her fierce desire / With my consuming fire." However, the sexual act resembles that of a praying mantis: "But while I love her she consumeth me; / She withereth my soul, that erst was free" (II). The first goddess seems to have used the poet to feed on his soul. The sexual intercourse with the second god is less voluntary and more straightforward:

The second god laughs loud upon my plaining,

Seeing in me his prey;

He girds austerely at my dreadful straining

To hold myself in play:

He hath no pity now (III).

In both of these images the poet is the quarry, though the strategies for ensnaring him differ. Whereas the first goddess uses the more subtle and feminine techniques of seduction, the second uses physical force to capture him, representing a more masculine and violent aspect of sexual intercourse. Both gods then exhibit the behaviour typically associated with the two sexes: the goddess stands for the soft, tender and yet deceitful feminine side, while the god personifies the aggressive and forthright masculine side. In both cases, it is a rather one-sided affair, the gods being the ones benefiting from the encounter; and, in both cases, the gender is clearly determined.

It is only in the encounter with the third god that the interaction ceases to be one-sided, in both ways - the pleasure of the sexual intercourse is shared, and the gender becomes much more ambiguous:

Lastly, there is one Great one, cold and burning,

Craft and hot in lust,

Who would make me a Sapphist and an Urning,

A Lesbian of the dust. (IV)

The third god transcends the dichotomy dividing the sexes, as the words "sapphist," "urning" and "lesbian" imply. What is more, his power to transcend gender boundaries is coupled with an ability to transform the gender and sexuality of others, as the verb "make" entails. The words "Sapphist" and "Lesbian" denote female homosexuality, deriving, as they do, from the Greek poet Sappho, residing on the isle of Lesbos. The less familiar word "urning" is a term Neuburg perhaps first encountered Carpenter's The Intermediate Sex. Originally the term had been used by the German jurist and writer Karl Heinrich Ulrichs to denote a person who belonged mentally to one sex, but physically to another (Carpenter 1912: 19-20). Carpenter explains that the origin of the term "urning" lies in the Greek word "Uranos," meaning "heaven" and that the idea was that "Uranian love was 
of a higher order than the ordinary attachment" (20). Neuburg was particularly interested in Carpenter's notion of the "doubleness of nature" (Owen 1997: 129), which does indeed resonate in the poet's encounter with the third god. In the poem, Neuburg "reworks [this concept], combining contemporary discussions of homosexuality with the enduring motif of the hermaphrodite. When he positions himself in his poem as both woman-desiring woman and man-desiring man, Neuburg is claiming a radically different 'hermaphroditism': two 'inversions' 'at once" (129-30). In fact, the poem reflects Neuburg's and Crowley's personalities and sexual preferences; the two men were sexually attracted to both men and women, and were not afraid to accept their feminine sides. In fact, Crowley "said the male magician must, without losing his virility, cultivate his female side" (Fuller 1990: 129). What is more, in Crowley's and Carpenter's thinking, these double-natured individuals anticipated a new age.

In his depiction of the three gods, Neuburg was probably inspired by The Book of the Law in which Crowley theorised three aeons of mankind: "the first aeon was that of the Goddess Isis, centred around matriarchy and the worship of the Great Mother; the second aeon was that of Osiris, during which the patriarchal religions of suffering and death-i.e., Judaism and Christianity-rose to power" (Urban 2004: 9). The first goddess would then be Isis, representing the age of matriarchy which is suggested by the goddess's femininity. The second god would be Osiris, representing the harsh age of Judeo-Christian patriarchy. ${ }^{3}$ This is symbolised by the god's violent masculinity, which is implied in the words "girds austerely" and "no pity." Moreover, this seems to echo Neuburg's poem "To Count Tolstoy" (published in the Agnostic Journal in 1904): "I will not crush my nature "neath my heel / To please a problematic, tyrant God" (qtd. in Fuller 1990: 104). The third god, the only one described positively in the poem, would then represent the age about to come. In the The Book of the Law, Crowley announced that "the world stood on the threshold of a new age - the New Aeon of Horus - the ruling characteristic of which is the unification of the male and female as represented in the androgynous figure of Horus" (Owen 1997: 126). The new age was supposed to have started in 1904 (Fuller 1990: 118). In the age of Horus, gender differences are finally transcended, which is expressed in the poem by the sexual union of the androgynous couple. What is more, in his encounter with the first two gods, the poet's freedom is restricted: the goddess "withereth [his] soul, that erst was free" and the god hinders his movement to be able to do with him as he pleases. This, too, is to be overcome in the aeon of Horus, which is to replace the two previous aeons "by freeing the power of the individual will" (Urban 2004: 17). The interpretation of the third god as Horus is also supported by the following lines:

The dung of all ages clings unto him,

And a fierce light shines through;

They are the dead who once, long, long since, knew him:

The Pagan and the Jew 
Have lent him, one by one,

Seed with their orison,

But he hath spurned their offerings, seeking me,

A god, a victim slain in majesty. (V)

Possibly, the words "The Pagan and the Jew," now "dead," refer to the past two aeons. The god whom Horus seeks, impersonated by the poet, could be Pan himself. The words "a victim slain in majesty" would then refer to the death of Pan with the arrival of Christ. "Pan's most ardent strife" might mean the rivalry between Paganism and Christianity. Another possible interpretation is that the third god, the "Great One," is Pan, "great" being a reference to Arthur Machen's influential novella The Great God Pan (1894). Moreover, Neuburg bestowed this epithet on Pan in the verse "The vision of great Pan" (XIII). The words "craft and hot in lust" in the fourth stanza would then point to Pan's deceitful nature and ravenous sexual appetites. Fuller offers yet another reading: she identifies the first goddess as Joan Hayes, Neuburg's lover, and the third god as Crowley. She was "unable to place" the second god "unless it be Pan himself" (1990: 162).

According to Crowley, the transition to the Age of Horus will be violent, "the nature of Horus being 'Force and Fire'" (Crowley qtd. in Churton 2012: 186), and this seems to be echoed in the poet's longing for the excitement of battle:

And storm the mountains; we are sick of dreaming

Of a dim past unknown;

Oh! for the sight once more of red blood streaming,

Of rotting warrior-bone,

Of eagles hovering far

Around the field of war,

Of lust and love and longing breaking through

The chill gray garb of life to flame anew. (XXIX)

The motifs of fighting, sex and passion share a certain intensity that contrasts with the dullness of the existing age. In fact, the celebration of invigorating barbarism in this stanza recalls Flaubert: "Perhaps we need barbarians. Humanity, the perpetual old man, requires infusions of new blood during his occasional agonies. How low we are! And what universal decrepitude!" (qtd. in Weir 1995, 28). In the stanza the contrast is expressed through the metaphors of fire and frost: through passion, be it in fighting or love, the "chill gray" world is melted. In fact, in the poem flame and fire are recurring metaphors expressing rejuvenation and positive change. Here is another example:

But roses, roses flame,

As ever, since they came

From the wild marriage-bed of young Desire,

And younger Love, the children of the Fire. (XL) 
The positive view of Desire and Love, "the children of the Fire," as agents of revitalisation, corresponds to Crowley's and Carpenter's views, according to which embracing sexuality is an inherent part of spiritual awakening. The motif of roses could be a reference to one of the parts of Crowley's Order of the Silver Star, ${ }^{4}$ namely the order of the Rose Cross, which — judging by its name - probably has roots in the Rosicrucian tradition. Owen explains that "the term 'Rosicrucian' derives from the name 'Rosencreutz' or 'Rose Cross"' (1997: 101).

Pan is then an apt herald of the transition to the new age, being characterised by unbridled sexuality. This, coupled with his goat-like features, encouraged his association with the devil, especially by Christians, and this connection is not omitted in the poem:

We found sleeping; yea, the Panic revel,

Had drawn his spirit far;

Asleep, he bore the aspect of a devil;

Awake, the morning star

Flashed in his eyes; oh, scan

The vision of great Pan;

Thrust tongue and limbs against his pulsing side,

And thou shalt know the dayspring as a bride! (XIII)

This passage refers to another transitional aspect of Pan; after "the Panic revel", at dawn he watched over the transition from night to day: "At night he led the dance of the nymphs, and he also ushered in the morning and kept watch from the mountain summits" (Kerényi 1974: 175). The last two lines in the passage suggest sexual union with Pan, a coupling which would help one share the experience of the transition, as the line "thou shalt know the dayspring as a bride" indicates. Interestingly enough, the word "dayspring," meaning the dawn, usually appears in a religious context and is most associated with the King James Bible (Job 38:12, Luke 1:78). Judging from Neuburg's and Crowley's shared attitude to Christianity, coupled with the fact that the word is used to describe a homosexual act, this phrasing can be considered one of the means of subverting Christianity within the poem.

The lustful Pan and Pan-like figures are-in the poem-closely connected with the abundant motifs of desire and longing:

My heart is broken, but mine eyes are tearless:

I seek the hidden grove

Where Pan plays to the trees,

The nymphs, the fauns, the breeze,

And the sick satyr with his syren-song

Makes the world ache with longing. I am strong. (X)

The grief-stricken poet is not without hope, for he is seeking Pan's grove and anticipating the rejuvenating pleasures that Panic revels offer. The word "sick" 
is here used in its now archaic sense, meaning "pining or longing for someone or something" (OED). The "syren-song" associates Pan and his companions with the beautiful and seductive femme fatales of Greek mythology, and hints at his more sinister aspects, a theme that is developed in the stanza following, in which the poem touches on Pan's corrupting influence:

This I can bear, though I am lone and cheerless,

A withered fruit of spring;

This I can bear, for all my soul is fearless,

So shall my soul not sing?

Rejoice that I am thine,

That I have given thee wine

From out my virgin heart, my stainless soul;

I am corrupted utterly; and whole. (XI)

Evoking the ritual sacrifice of virgins, the poet offers up his innocence to the god of lust. Wine is an especially apt metaphor here. First, wine as an alcoholic drink provokes lust on a chemical level. Second, it draws on the imagery of sacrifice as it resembles blood. Moreover, wine represents the blood of Christ, commemorating his sacrifice for mankind. And as Christianity and Paganism are often opposed to each other, the corruption of the young poet offering himself to the Pagan god would be all the more acute. It would also invert the relationship of Pan and Christ, since Pan's death is announced with the coming of Christ. In this imagery, however, Christ would be sacrificed to Pan. Finally, wine is closely associated with Pan (and Bacchus) and hence an appropriate offering for them. Moreover, there is a reference to "wine, / Fresh from the Bacchic vats, and foaming grape" (XXVI) later in the poem.

There is a strong contrast between the poet and those he calls "slavish singers." These could be Neuburg's and Crowley's contemporaries, representing what Crowley hated and fought against: Christianity and conformity. According to Tobias Churton, his biographer, Crowley was "implacably opposed to . . . sexnegative, evangelical beliefs" (2012: 6). In his view, the sin "lies in treating sex at the level of base instinct, smothering it with guilt and shame. Such conduct degrades and blasphemes a holy sacrament" (138). Accordingly, in Crowley's teaching, sexuality and spirituality are inherently connected, and, what is more, the unity of the two is crucial for a free and vigorous society: "Deprived of the power to combine physical and spiritual love, the world is a waste. Magick would restore light, life and liberty to the wasteland" (6-7). Carpenter held a very similar view. Observing a Hindu festival, he saw that "sexual energy seemed to charge spiritual ecstasy" (Rowbotham 2009: 153). He believed that "the fierce, earthy passions were 'half the driving force of the soul', while 'sensuality ... underlies all art and the high emotions'. ${ }^{15} \mathrm{He}$ wanted to validate physical desires denigrated by Christianity" (Rowbotham 2009: 147). He expressed these ideas in his prose poem Towards Democracy (1883): "Sex still goes first, and hands eyes mouth 
brain follow; from the midst of belly and thighs radiate the knowledge of self, religion, and immortality." (Carpenter 1896: 18; see also Rowbotham 2009: 74). Neuburg undoubtedly shared many or all of these views. Indeed, Fuller suspects that his poem "To Count Tolstoy" "must be the reply to some diatribe on chastity. This, says Victor, may be all right when one is ninety-one, but he is only twenty now and means to have some fun!" (1990: 104). That is why he "will not crush [his] nature "neath [his] heel / To please a problematic, tyrant God" (qtd. in Fuller 1990: 104). Accordingly, the twelfth stanza of the poem can then be read as a condemnation of conformity and the "sex-negative" Christianity (the second aeon):

The slavish singers of the barren years,

What have they left to say?

Upon the Moribund they waste weak tears,

And slobber o'er dull day.

But we, my God, have been

Sublimely wise; obscene

In passion; and her light is round us strown;

We have enmeshed in passion's web the Unknown. (XII)

The words "barren," "weak," "moribund" and "dull," coupled with the question, describe a dying and stagnating world in desperate need of change. By contrast, the poet and the god are very much alive, which is implied in the sexually charged words "passion" and "obscene." What is more, they are the ones who have something to say, some wisdom to convey. What is implied here is that wisdom lies in gratifying one's desires rather than in curbing them, an idea redolent of Decadent hedonism. The critique of the compliant "slavish singers" continues in the fifteenth stanza:

What do they know of joy? They tamely wander In barren paths and straight;

With down-cast modest eyes they sit and ponder

Outside the mystic gate. (XL)

The atmosphere that is evoked by these lines is that of passivity and surrender. The slavish singers sheepishly follow the "straight" paths of tradition and convention, and, in their modesty, do not have enough courage to stray. They "sit and ponder," but the words "outside the mystic gate" indicate that their religion is mistaken; they have not managed to get inside and discover mystical truth. While this is one possible reading, one must bear in mind that this is a Decadent poem about sexual inversion; hence it is infused with homoeroticism. Consequently, conformity in this stanza can be narrowed down to the sphere of sexual behaviour. Another meaning of the word "straight" is "heterosexual" and the mystic gate probably symbolises the bottom, which is further supported by the word "sit," the reader's attention being drawn to that part of the body. Sitting "outside 
the mystic gate" then means the exclusion of the slavish singers - the compliant Christians - from homoerotic practices.

However, the slavish singers are not just passive unhappy creatures; they are active agents responsible for death and stagnation:

They cast out Love, but Love for aye hath dwelling,

Sleeping, within the spirit;

They have murdered Joy, but Joy reborn is swelling

In earth, and shall inherit

Anew the realm of Time

And earth shall grow sublime ... (XVI)

The line "They cast out Love" may mean the repression of sexuality in general (in Christianity) or homosexual love in particular. The poet, however, believes that this wrong will be redressed, and the second part of the stanza contains the anticipation of the rejuvenating Pagan Spring.

In the thirty-eighth stanza, this joyful expectancy is reiterated when the poet expresses his desire to "right the ancient wrong," probably referring to the "death of Pan" at the arrival of Christ, and the intention to bring back the Pagan past:

Oh, shadows, shadows, shadows, shadows ever;

They lisp, the fools, their song:

But where is fled the lusty, wild endeavour

To right the ancient wrong?

They mouth their feeble prayer

Unto the empty air. ...

But we will bring the past, the past, again,

The lust of joy, the rapture and the pain! (XXXVIII)

The first part of the stanza is concerned with the slavish singers, whose delusion is evoked by the image of shadows, suggestive of Plato's Allegory of the Cave, and, in fact, Neuburg was "an agnostic platonist" (Fuller 1990: 107). Their "feeble prayer," (contrasting with the intense "joy," "rapture" and "pain") goes unheard; they lisp it "unto the empty air," implying again that their religion, Christianity, is mistaken. There is no god to hear them.

The interpretation of the "ancient wrong" as the death of Pan is supported by the two stanzas directly preceding the thirty-eighth stanza, considered above, possibly describing the end of Paganism:

And lo! We find the Panic revel over, The cups down-turned; the grape

Is trampled level with the lowly clover;

There is no brooding shape,

Bright-eyed, bright-winged, and strong 
As a piped mountain-song

In the keen Alpine air: No joy is here,

Only the shadow of man's foolish fear. (XXXVI)

The lively world of Panic revels is trampled by the fearful and gloomy age of Christianity. The wine grapes, associated with Bacchus and Pan, are crushed and are now no more important than "the lowly clover," which, ironically, came to symbolise the Christian Trinity. The mournful tone continues in the following stanza, describing Pan's dethronement and the disappearance of his followers:

The revellers are fled; where, no man knoweth,

Save it be whence they came;

The chill, dull wind of desolation bloweth

Upon the flickering flame

Of the old lost delight:

There is no garland bright

On the brows of the old Hermaphrodite, whose eyes

Glowed ever newly once with new surprise. (XXXVII)

The absence of a garland on Pan's head perhaps symbolises the loss of his power and of joy and vitality in general, all extinguished by the "chill, dull wind" of the Judeo-Christian. Calling Pan the "Hermaphrodite" gives prominences to his ability to transcend gender boundaries, possibly connecting the strict gender division in the austere Judeo-Christian world with the loss of joy.

In accordance with the motifs of desire and passion permeating the poem, the climax — "the Pagan spring" — is described in a sexual tone:

Grant me again thy lyre! Let me awaken

The old eternal spring;

So shall each soul with pangs of birth be shaken,

Let the good juices sting.

The song I craved is mine,

Thy song of blood and brine;

Men shall stand unashamed and free,

To flaunt abroad their new-born ecstasy! (XLII)

These lines could be read as an expression of a desire to break free from a world governed by austere Christian morality. Unlike Adam and Eve after the Fall, men shall be naked and unashamed again. Correspondingly, the language Neuburg uses in describing the revolution consists of metaphors referring to the body and bodily fluids - "the good juices," "blood and brine," words suggestive of semen and sweat - as well as physical pleasure. In fact, the poem seems to echo Carpenter's Towards Democracy, in which he speaks of "a time when men and women all over the earth shall ascend and enter into relation with their bodies-shall 
attain freedom and joy" (Carpenter 1896: 5; see also Rowbotham 2009: 74). The following example, from an earlier part of Neuburg's poem, is characterised by a similar tone and sexually charged language:

The fire of generation, the salt juices

Within my body rare,

Shall remedy our winter-time abuses;

The odour of thy hair,

Thy feet, thy hands, shall bring

Again the Pagan spring,

And from our bodies' union men shall know

To cast the veil from the sad face of woe ... (XIV)

The sexual language of the poem, focused on the body, stands in direct opposition to the typically Christian detachment from the body and its focus on the soul, implying that the soul cannot thrive without the body. Correspondingly, the rejuvenation of the body goes hand in hand with the revitalisation of the soul.

Two prominent metaphors in the description are wine and ecstasy, both of which, as has already been noted, are associated here and elsewhere with Pan and Dionysus; these are the means and the effect of the Pagan spring:

It shall be mine, O Master, in my singing

To call the brooding light

Back to the earth; would that my soul were winging

To victory through the night!

Yea! And it shall be mine

To pour the sacred wine,

And make men drunk with ecstasy as I,

Drunken with joy whether I live or die. (XXXIX)

In this context, "the sacred wine" is liberating in its effect of loosening the inhibitions, which makes it easier to break the long established conventions and the deeply ingrained, and yet false, convictions. This interpretation is further supported by the forty-first stanza, in which the same theme appears:

Give me thy wine! So shall my song unending

Break through the barren prayer

Of fear and fashion; let the mystic blending

Of perfumes fill the air

With hues of light and things

Unutterable; the stings

Of joy shall pierce men's hearts, and there shall be

Unending, throbbing, passioned ecstasy. (XLI) 
The words "fear and fashion" could be read as convention and the fear of breaking it. While the word "barren" implies not only the suppression of sexuality, which is countered by the sex-and-body-embracing "throbbing, passioned ecstasy" at the end of the stanza, it also suggests a stifling of creativity, to which a blind following of tradition and convention leads.

At the end, as was foreshadowed by the title, Pan regains his power and, with him, the world of revels, feasting and joy:

Grant me, Eros, thy kiss,

That I may speak thy bliss-

The revel and the rapture and the feast,

The Pæan, and the Crowning of the Beast! (XLIII)

The phrase "the Crowning of the Beast" can be read in several ways. Apart from the half-human, half-goat god Pan, it may refer to Crowley, whose famous moniker was "Beast 666." ${ }^{5}$ The moment of triumph is anticipated earlier in the poem and described in very ecstatic language, suggestive of orgasm: "There shall be no despair, / But Pan! Pan! Pan! and all the world shall be / Mingled in one wild burning ecstasy" $(\mathrm{XV})$. In the last stanza, the poem reaches its triumphant climax:

Yea! And the lyre is mine, and I am fearless,

Naked, and free, and young;

The torch is out; no longer night is cheerless;

The hot young day is sprung

From out the loins of God!

Rise from the barren sod,

Raise high the Pæan of the God in Man!

Io Triumphe! / Hail to the new-born Pan! (XLIV)

The "barren sod" of the world governed by Christianity is rejuvenated from the seed from the fertile loins of the Pagan God, and the poet is liberated from the grim chains of Judeo-Christian constriction. The verse "the God in Man" reflects Crowley's teaching in which the aeon of Horus is marked by "the emphasis . . . on the self or will, not on anything external such as gods or priests" (Symonds qtd. in Urban 2004: 9), corresponding to the emphasis on individuality which characterises Modernism during this period.

On the whole, the poem is characterised by a sharp dichotomy between two worlds: that of a cold, dull, dead and desolate world, populated by obedient "slavish singers" whispering their "feeble prayers" to a god who does not hear them, and a lively world of revels, in which sexuality is liberated and gender is not restricted to two prescribed roles, making place for individuality. In accord with Neuburg's and Crowley's hatred of Christianity and organised religion, the first world, figured as the second aeon in Crowley's The Book of the Law, will be overcome by the third aeon of Horus. In the poem, the dead world is reborn dur- 
ing the Pagan spring, a time when Pan's world of revels, feasting, joy, rapture, and ecstasy returns. The coldness of death is replaced by the warmth of passionate life, conveyed by the metaphors of fire and flames. What these elements have in common is intensity of experience and emotion; they spark life into the world of resignation, combating dullness and despair. People are not slaves to the austere Judeo-Christian morality any longer; they stand naked and free, unashamed of their bodies and bodily needs, which are amply illustrated in the sexual tone which permeates the poem. The poem thus seems to contrast two approaches to life: it celebrates hedonism, expressed in the motifs of wine, ecstasy, body and an overall embracing of intense experience, characteristic of Decadence, Crowley's sex magic and Carpenter's positive view of the body and its pleasures. ${ }^{7}$ And it criticises asceticism pursued in the poem by the "slavish singers" representing the austerity of certain segments of Victorian England, particularly what Crowley saw as "self-denying Christendom" and what Neuburg saw as people under the yoke of the "a sky-seated tyrant he was sure was non-existent" (Fuller 1990: 121).

In fact, what Crowley, Carpenter and Neuburg fought against can also be expressed by Showalter's metaphor of syphilis, representing the fear of sex and the resultant repressive attitude towards it:

For the male literary avant-garde [...] syphilis was the excrescence of a sexually diseased society, one that systematically suppressed desire and so produced anxious fathers and divided and disfigured sons. In the work of such writers as Ibsen, Stevenson, Hardy, Wells, and Joyce, the sins of the fathers are not lust and vice, but ignorance, guilt, shame, and fear. [. . .] Ibsen's ghosts are not the invisible spirochetes of syphilis but the virulent prohibitions of religion and bourgeois morality. Mistaken ideas about sexuality constitute the true hereditary taint: "It is not only what we have inherited from our fathers and mothers that exists again in us, but all sorts of old dead ideas and all kinds of old dead beliefs [...] They are dormant, and we can never be rid of them. [...]" (2010: 199-200)

Crowley, Carpenter and Neuburg did their best to fight these old beliefs and Neuburg's poem expresses the hoped for triumph.

In many ways, the poem reflects the Zeitgeist of a world in transition. Christianity had lost much of its power, and writers such as Neuburg, Crowley and Carpenter had found better alternatives in Eastern religions and Paganism, all of which grew in popularity and relevance during their period, because, instead of denying the body and sexuality, they embraced them. This embracing of sexuality went hand in hand with a blurring of gender boundaries, starting in fin de siècle in the figures of Decadent Dandies and New Women, who often shocked the public by being effeminate or too masculine, respectively. Both were often a reaction to the prudency and strict gender division of Victorian England. Even more importantly, gender boundaries were becoming more indistinct in the emergent homosexual culture, especially in one of the models of homosexual identity: 
According to this model of border-crossing and liminality, gay people were an "intermediate sex," "exactly at the threshold between genders." ${ }^{14}$ Homosexual men were people born with a high percentage of essential femininity, with a "woman's soul trapped in man's body." Homosexual women were mannish lesbians, women with a high percentage of essential masculinity. ${ }^{6}$ (Showalter 2010: 172)

This model corresponded to Carpenter's notion of double-natured individuals, or "the intermediate sex," and is celebrated in Neuburg's figure of Pan as Hermaphrodite. "The Triumph of Pan" then anticipates a triumph of sex-embracing and rejuvenating Paganism over sex-negating and stifling Christianity, a triumph celebrating fluid sexual and gender boundaries and denouncing the constricting black and white division of gender identities, a triumph symbolised by the god Pan, the Hermaphrodite.

\section{Notes}

1 The more common name of the order is A $\therefore$ A $\therefore$ The letters A probably refer to "Astrum Argentinum," which is Latin for "Silver Star" and the dots are possibly a reference to "spiritual activity, derived from 17th-century Rosicrucian sources" (Churton 2012: 124). The order was supposed to "eschew formal religious, moral codes, concentrating on communicating with the 'True Will' or the 'Knowledge and Conversation of the Holy Guardian Angel': the individual's hidden essence" (143). And to root out the inculcated moral convictions in his chela, Crowley often made Neuburg pay a visit to a brothel as part of the "A $\therefore$ A $\therefore$ 's balancing regimen" (149).

2 The Book of the Law (Liber Legis) was Crowley's most famous work. He claimed that it has been dictated to him by his guardian angel Aiwass (Urban 2004: 9-10).

3 The austerity and sternness of Judaism and Christianity had been noted by others as well, for example by Matthew Arnold in his Culture and Anarchy (1869). As Philip Davis points out, Arnold criticises the power of morality and conscience typical for "the stern Hebraic worldview," which was "still strong in the first half of the nineteenth century," and emphasises the need for liberation from "the grim chains" of the strict Hebraic view in the period that followed (2008: 17).

4 The Order of the Silver Star, the A $\therefore$ A $\therefore$, consists of three parts: "the order of the Silver Star proper (the 'Secret Chiefs'), the second order of the Rose Cross, and the outer order of the Golden Dawn, putting the Golden Dawn in its place" (Churton 2012: 146).

$5 \quad$ In Crowley's case, "Beast 666" does not signify the devil, as is commonly assumed. In the Bible, the "beast" represented "the Roman Empire, which had initially impinged upon Judean consciousness from across the Mediterranean Sea" (Asimov 1981: 1211). The number was used to denote a particular man, possibly Nero, whom the author of Revelation could not name directly for fear of persecution (1213). Churton explains that the "beast" "became a symbol for the Roman Empire, scourge of the Church," but Crowley "interpret[ed] it as the Sun, or light source" (2012: 6). Moreover, his mother called him "the Beast" (6).

6 A second model is the opposite: homosexual people are seen not in the middle of the masculine-feminine scale, but at the extremes: "The second model . . . saw homosexuality as the "highest, most perfect evolutionary stage of gender differentiation' ${ }^{17}$ " (Showalter 2010: 173). Homosexual men and women represented then "heightened forms of masculinity and femininity and were the most purely 'manly' or 'womanly' representatives of their sex" 
(173). The reason they were attracted to their own sex was because of their hatred of the other sex (173).

However, Carpenter, as an avid socialist, did not advocate pleasure for its own sake; he did not approve of pursuing pleasure at all costs. Rather, he believed that one should enjoy the moments of pleasure when they come and not suppress them: "Carpenter is careful to distinguish himself from the 'Decadents" delight in sensation: 'The maximum of enjoyment is not got by the pursuit of Pleasure; but rather by going your own way and letting the pleasure pursue you. ${ }^{43 "}$ (Rowbotham 2009: 255).

\section{References}

Asimov, Isaac (1981) Asimov's Guide to the Bible. New York: Wings Books.

Carpenter, Edward (1912) The Intermediate Sex. New York: Kennerley.

Carpenter, Edward (1896) Towards Democracy. Manchester: Labour Press.

Churton, Tobias (2012) Aleister Crowley: The Biography. London: Watkins Publishing.

Davis, Philip (2008) Why Victorian Literature Still Matters. Malden MA and Oxford: John Wiley \& Sons.

Fuller, Jean Overton (1990) The Magical Dilemma of Victor Neuburg. Oxford: Mandrake.

Kaye, Richard A. (2007) "Sexual Identity at the Fin de Siècle.” In: Marshall, Gail (ed.) The Cambridge Companion to the Fin de Siècle. New York: Cambridge University Press, 53-72.

Kerényi, Karl (1974) The Gods of the Greeks. London: Thames and Hudson.

Neuburg, Victor Benjamin (2009) The Triumph of Pan. Austin: Monkey Press.

Owen, Alex (2004) The Place of Enchantment: British Occultism and the Culture of the Modern. Chicago and London: The University of Chicago Press.

Owen, Alex (1997) "The Sorcerer and His Apprentice: Aleister Crowley and the Magical Exploration of Edwardian Subjectivity." Journal of British Studies 36 (1): 99-133.

Rowbotham, Sheila (2009) Edward Carpenter: A Life of Liberty and Love. London and New York: Verso.

Showalter, Elaine (2010) Sexual Anarchy: Gender and Culture at the Fin de Siècle. London: Virago. Urban, Hugh B. (2004) "The Beast with Two Backs: Aleister Crowley, Sex Magic and the Exhaustion of Modernity." Nova Religio: The Journal of Alternative and Emergent Religions 7 (3): $7-25$.

Weir, David (1995) Decadence and the Making of Modernism. Amherst: University of Massachusetts Press.

Eva Valentová is currently doing her Ph.D. in the Literatures in English programme at the Faculty of Arts at Masaryk University in Brno, Czech Republic. She holds combined MA degrees in English Language and Literature and German Language and Literature, and in Teacher Training. Her research interests include fin de siècle, Decadence and the trickster figure. She wrote her MA thesis on Peter Pan as a trickster figure and, in her Ph.D. project, she focuses on the role of the Greek god Pan in Decadent literature.

Address: Mgr. Eva Valentová, Department of English and American Studies, Faculty of Arts, Masaryk University, Arna Nováka 1, 60200 Brno, Czech Republic. [email: valentova.eva@gmail. com] 
